Sin duda muchos de los hechos aquí comentados están en función de conseguir esta denominada disciplina, sin embargo gran parte de ellos lo único que suelen provocarnos es perplejidad. La disciplina en estos recintos se transforma en una manera de homogeneizar, bajo reglas aparentemente comunes, comportamientos completamente diversos y disímiles. Y en ello la arquitectura juega un importante rol. La arquitectura no es sino el último eslabón de la cadena que comienza con la formatización del cuerpo, corte de pelo, vestimenta, marca, etc., y que termina con la homogeneización del espacio. Este proceso que nos lleva de ser individuos a ser por una horas "masa", no tiene sino el efecto de provocar en nosotros un sentimiento de privación de libertad y expresión. Ante pabellones iguales, salas iguales, puertas iguales, bancos iguales, no somos nombres sino más bien números. $\mathrm{El}$ mensaje es claro: la individualidad no tiene cabida. Somos hormigas y abejas que tienen que cumplir un rol determinado. Todo esto obviamente tiene algún efecto, pero la gran duda que muchas veces plantea está en la idoneidad de los que manejan el proceso. El amplio espectro de caracteres que desfila ante nuestros ojos nos hace pensar que lo único regular y homogéneo es la arquitectura, pues todo el resto es de una blandura que nos hace reflexionar en que muchas veces estos establecimientos se convierten en presidios tanto para alumnos como para profesores. Hay una dosis de locura presente en toda enseñanza, en todo método educacional, en todo educador, en todo sistema que tienda a la rigidización y homogeneización de los individuos, pero que es a la vez una locura liberadora. Son esa locura e irracionalidad, las que nos permiten escapar de esa prisión física a que se someten nuestros cuerpos y nuestras mentes; así, podemos soñar estando en estas cárceles de cemento, y reírnos después de todo al darnos cuenta que esto no es sino otro de los juegos y sistemas que gustamos de inventar, para al menos creer por unas horas que vivimos en un mundo completamente ordenado y reglado. Una más de tantas invenciones humanas; y por lo tanto, tremendamente falibles. ARQ

Bibliografía: Jaldun, Ibn (historiador árabe, 1332-1407); Al-Muqa ddima (Introducción a la Historia Universal). I Prost, Antoine y Vincent, Gerard; La vida privada en el siglo XX. Editorial Taurus, Madrid, 1989.

\section{La educación en el cambio de siglo Malva Villalón}

En el verano de 1920 Jessie Stanton elaboró un perfil del profesor ideal: La educadora infantil debería tener un físico fuerte, una personalidad agradable y modales tranquilos y firmes. Ser equilibrada y con un carácter moral sólido, fuerte pero no impetuosa, al ser mordida o rasguñada. Su educación debería incluir un doctorado en psicología y medicina, siendo aconsejable que cuente también con estudios de sociología. Su formación tendría que incluir, al menos, cinco años de práctica en carpintería, gasfitería, música y poesía. Tener la capacidad de observar a las personas y evaluar su carácter, relacionándose con gente de todas las edades. Ser capaz de hipnotizar a los padres de sus jóvenes alumnos, y lograr que cambien su forma de pensar luego de dos reuniones de apoderados (Stanton, 1920) ${ }^{1}$. En este perfil es posible reconocer la influencia del filósofo y pedagogo John Dewey (1859-1952), para quien la democracia es la fuerza rectora de la educación y quien concibe la experiencia como expression. Faced with identical classrooms, identical buildings, identical doors and benches, we no longer have names but only numbers.

The message is clear: there is no room for individuality. We are bees and ants, with a predetermined role to play. All this obviously has an effect but the biggest doubt is over the suitability of those who manage this process. The broad range of characters who parade before us makes us think that the only regular homogeneous aspect is the architecture, for all the rest is so soft it suggests that very often these establishments become prisons for both students and teachers. There is madness in all teaching, all educational methods, all teachers, all systems that tend to make individuals rigid and uniform, but it is also a liberating madness. This madness and irrationality allows us to escape from the physical prison that holds our bodies and our minds, and we can dream, while still held in cement prisons and laugh, after all, as we realize this is only another of the games, the systems we like inventing, to be able to believe for a few hours that we live in a well-ordered world. It's just one more human invention, and for that reason - very fallible. ARQ
Bibliography: Jaldun, Ibn (arab historian, 1332-1407); Al-Muqaddima (Introduction to Universal History). I Prost, Antoine and Vincent, Gerard; La vida privada en el siglo XX. Editorial Taurus, Madrid, 1989.

\section{Education at the turn of the century \\ Malva Villalón}

Doing 1920's summer, Jessie Stanton defined the ideal teacher profile: The infant teacher should have a strong physique, a pleasant personality and quiet but firm manners. She must be well balanced, with a solid moral character, strong but not rash when bitten or scratched. Her education should include a doctorate in psychology and medicine, and some knowledge of sociology would also be advisable. Her training should include at least five years' practical experience of carpentry, plumbing, music and poetry. She must be observant and a good judge of character, able to relate to people of all ages. She must be able to hypnotize the parents of her young students so they change their ways of thinking after just two parent teacher meetings. (Stanton, 1920) ${ }^{1}$.

This profile reveals the influence of the philosopher and pedagogue John Dewey (18591952), for whom democracy was the guiding light of all education, and who saw experience as the 


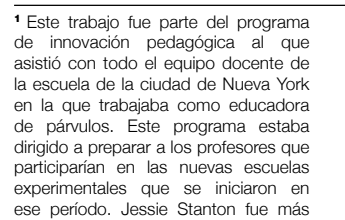

tarde reconocida como una autoridad en educación infantil, como directora
de un centro educativo y profesora de la Universidad de Nueva York, además de autora de numerosos artículos especializados. Su ensayo acerca del profesor ideal fue publicado en 1954 y nuevamente en 1990, como un
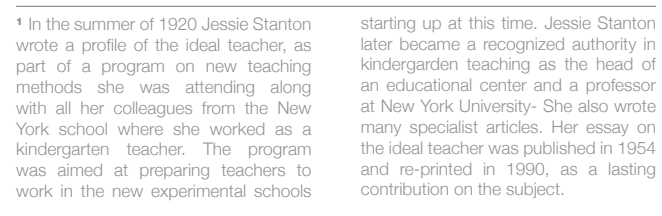

el origen del conocimiento y del desarrollo de las personas. Sus ideas guiaron los movimientos pedagógicos iniciados a comienzos del siglo XX. En un período de fuerte expansión de los sistemas educativos, se buscó renovar, a partir de sus principios, la educación en las escuelas y desde éstas a la sociedad completa (Ravitch, 2000). En un tono ciertamente humorístico, este perfil del profesor ideal propuesto al inicio del siglo pone de relieve la amplitud de las demandas impuestas al profesional de la educación. Su figura aparece como la clave del proceso educativo, dotado de unas condiciones personales y de una formación amplia que lo hace capaz de enfrentar en solitario las resistencias de los niños y compensar la falta de preparación de los padres de familia para hacerse cargo de la educación de sus hijos. Estos ideales, así como la época y el contexto en el cual surgen, pueden ser vistos como una de las claves fundamentales para comprender el cuestionamiento al que está sometida la educación escolar en la actualidad.

El proceso de desarrollo de los sistemas escolares alcanzó mayor fuerza desde la segunda mitad del siglo XIX y el comienzo del siglo XX, potenciado por la convergencia de demandas de desarrollo de distinto origen. Por una parte, los requerimientos de personal cualificado desde el sector productivo; por otra, las presiones sociales dirigidas a lograr una mayor igualdad de oportunidades y también la influencia del pensamiento ilustrado, que relaciona el acceso al conocimiento con una mayor equidad social. En este contexto, los sistemas escolares nacionales fueron vistos como el medio más adecuado de responder a estas demandas, compensando las desigualdades determinadas por la situación familiar, especialmente en el caso de los grupos más pobres y marginados. Se instauróla educación básica obligatoria, la que fue complementada con programas de atención a la infancia y con la oferta de programas de educación secundaria, tanto en los países industrializados como en los países en desarrollo más avanzados del mundo occidental (Delors, 1996). Esta concepción de la educación como aspecto clave del cambio social y como tarea del Estado también se hizo sentir en nuestro país.

La consigna "Gobernar es educar" que presidió la campaña que llevó a Pedro Aguirre Cerda a ser elegido Presidente de Chile en 1939, ilustra la relevancia de esta convicción en las políticas gubernamentales de la época, como parte de una tendencia que marcó el desarrollo de los países origin of knowledge and personal development. His ideas guided the teaching movements at the beginning of the $20^{\text {th }}$ century. At a time when educational systems were expanding fast, his principles formed the basis of a renewal in education in the schools, and from them to the rest of society (Ravitch, 2000). The humorous profile of the ideal teacher illustrates the breadth of the demands on these professionals. The teacher is seen as the key to the educational process, with the personal skills and extensive training that equip him to face, alone, the resistance of the children and compensate for the parents' lack of preparation as educators. These ideals, and the period and context in which they arose, are fundamental factors to understanding today's questioning of school education.

The development of school systems reached its height between the second half of the $19^{\text {th }}$ and the beginning of the $20^{\text {th }}$, century, driven by converging demands from different areas. The productive sector was calling for skilled workers; there were social pressures to achieve more equality of opportunities; and there was the influence of enlightened thinkers who related access to knowledge with greater social equality. The national school systems were seen as the best means of meeting these demands and compensating for the inequalities created by family conditions, particularly in the poorest sectors. Primary education was made obligatory, supplemented by programs for pre-schoolers and by the offer of secondary schooling programs, in both the industrialized and the more advanced developing countries of the west (Delors, 1996). This particular view of education as a key aspect of social change and a task for the state also emerged in Chile.

In 1939 Pedro Aguirre Cerda was elected President on the campaign slogan: "To govern is to educate", signaling the importance of this conviction in government policy at the time, and part of a trend that marked national development everywhere throughout the century. Efforts and resources went into building and equipping schools in order to guarantee the access of the infant population to primary education (Barnard, 2000). School buildings became familiar landmarks in the urban landscape, and the social forms of school culture connected with the mainstream of social life in all social sectors. The steady development of school systems meant that a lo largo del siglo. Los recursos y esfuerzos se orientaron a garantizar el acceso de la población infantil a la educación básica, a través de la construcción y la dotación de escuelas (Barnard, 2000). Los edificios escolares se convirtieron en un elemento característico del entorno urbano, tanto como las formas sociales propias de la cultura escolar se articularon con el resto de la vida social de todos los sectores. El desarrollo sostenido del sistema escolar llevó a que los profesores llegaran a ser uno de los grupos profesionales más numerosos en todos los países. Diversos especialistas de distintos ámbitos influyeron en la introducción de cambios en los métodos pedagógicos, los objetivos y los contenidos curriculares, los materiales educativos y la formación de los profesores, los sistemas de evaluación y promoción del sistema escolar, buscando incorporar a la enseñanza los hallazgos de la investigación científica y la innovación tecnológica. La profundidad y el ritmo de estos cambios no fueron los mismos en todos los países, influidos por la presión de distintos grupos e instituciones sociales y por la mayor o menor disponibilidad de recursos, pero la tendencia universal fue de un creciente reconocimiento de la importancia de la educación para el desarrollo everywhere teachers became one of the most numerous professions. Experts in different areas contributed to bring changes in teaching methods, the aims and contents of the curriculum, teaching materials and training, and the evaluation and promotion of the school system, as they sought to incorporate the findings of scientific research and technological innovations. The depth and speed at which these changes occurred differed from country to country, varying with the pressures of different social groups and institutions, and the availability of resources. But the overall trend was a growing recognition of the importance of education for social and economic development (Delors, 1996).

The increase in the economic resources earmarked for education over the century led to growing interest in the results being achieved by the school system - interest which has intensified in recent decades. Studies in Chile like 'La escuela ¿Cómplice del fracaso escolar?' (Schools: Accomplices in student failure?) (Filp, Cardemil, Donoso, Torres, Diéguez and Schiefelbein, 1981), and in the USA, 'A Nation at Risk' (National Commission on Excellence in Education, 1983), reveal the atmosphere of 
social y económico (Delors, 1996).

El aumento de los recursos económicos destinados a la educación a través del siglo llevó a un interés creciente por los resultados alcanzados por el sistema escolar, que se hizo más amplio durante las últimas décadas. Títulos como "La escuela ¿Cómplice del fracaso escolar?" (Filp, Cardemil, Donoso, Torres, Diéguez y Schiefelbein, 1981), publicado en Chile o "Una nación en riesgo" (National Commission on Excellence in Education, 1983), en Estados Unidos, permiten ilustrar este contexto de preocupación y denuncia. Durante la segunda mitad del siglo $\mathrm{XX}$, y especialmente desde la década de los setenta y los ochenta, comenzaron a implementarse sistemas de evaluación de los aprendizajes escolares, primero a nivel local y luego a nivel nacional e internacional, estableciéndose comparaciones entre distintos segmentos de la población (Marchesi y Martín, 1998). Los resultados obtenidos mostraron la distancia existente entre las metas propuestas y los logros alcanzados en la asimilación de aquellos conocimientos definidos como básicos para que las personas puedan participar plenamente de la vida en sociedad. Desde entonces se han multiplicado los informes que muestran las dificultades que presenta una mayoría de los alumnos de distintos grados escolares y los egresados del sistema escolar, para resolver problemas matemáticos, comprender lo que leen y expresarse por escrito de acuerdo a los objetivos de los programas cursados (Bruer, 1993). Estas dificultades han probado ser aún mayores para los grupos más vulnerables de la sociedad, entre los que se dan niveles altos de repitencia y deserción escolar. Como consecuencia de este panorama, el interés de los especialistas se ha centrado en la identificación de los factores que determinan la calidad de la enseñanza. Los métodos pedagógicos, las actividades de aprendizaje, el papel del director en la gestión escolar y las relaciones de los centros educativos con las familias y el contexto social inmediato son algunos de los aspectos que han sido reconocidos como los más relevantes para mejorar el rendimiento de los alumnos (Marchesi y Martín, 1998).

Los antecedentes aportados por estos estudios han servido de base para el desarrollo de programas de intervención orientados a lograr una educación más efectiva a partir de la realidad de las escuelas. En este contexto, el perfil del profesor ideal no corresponde al planteado al inicio. El número de profesores que se requiere para atender a toda la población infantil y juvenil no permite esperar una homogeneidad en las características personales de los profesores, tampoco en la calidad de la formación inicial recibida (Delors, 1996). Diversos estudios muestran que en los centros de calidad el desempeño efectivo aparece como el resultado de un trabajo colaborativo de todo el equipo docente del centro escolar y no como un producto del esfuerzo individual de cada profesor con sus alumnos (Barberá, 2003). Tampoco el período de formación profesional inicial resulta suficiente para que los profesores puedan cumplir con su tarea, en una sociedad en la que el conocimiento se renueva de una manera acelerada. Esta formación sólo puede plantearse como la primera etapa de una formación que debe ser continua. Por otra parte, más que imponer a los padres sus puntos de vista, se ha demostrado que es preciso que los profesores valoren y tomen en cuenta la influencia de la familia en el proceso de aprendizaje. De esta forma se logra que ésta se potencie a través de la educación escolar y que se alcancen los resultados de aprendizaje esperados. Sin embargo, frente al optimismo de esta postura, representada por quienes creen que el problema está en identificar y superar los concern and criticism. In the second half of the $20^{\text {th }}$ century and particularly since the 1970 s and 1980s, systems began to be put in place to evaluate schooling, first locally and then nationally and internationally, in order to be able to compare results in different segments of the population (Marchesi and Martin, 1998). The evaluations showed up the gap between the targets and the results in transmitting the basic knowledge and skills that individuals need to function fully in society. Since then, there have been endless reports showing the difficulties experienced by most students at different stages of schooling and most school leavers in meeting the program objectives for solving mathematical problems, understanding what they read and expressing themselves in writing (Bruer, 1993). These difficulties are more acute in the more vulnerable social groups, where students often repeat a year or leave prematurely. As a result, the experts have concentrated on identifying the factors that determine teaching quality. Teaching methods, learning activities, the role of the head of school as manager, relations between the educational centers and the families and the immediate social setting are some of the factors that have emerged as relevant in improving student performance (Marchesi and Martin, 1998).

Information from these studies has contributed to developing programs aimed at achieving a more effective education, based on the situation in the schools. The profile of the ideal teacher no longer fits the model quoted earlier. The number of teachers needed to cover the entire infant and youth population does not allow for homogeneity in their personal characteristics or in the quality of their initial training (Delors, 1996). Various studies show that in quality educational centers, effective performance is the result of a collaborative effort by the entire teaching team, rather than the result of individual effort (Barberá, 2003). The initial period of teacher training is also insufficient in a society where knowledge has to be renewed at an ever faster rate, so it has to be seen as only a first stage in a continuous process. And rather than imposing their viewpoint on the parents, teachers need to value and take into account the influence of the family in the learning process, strengthening and amplifying this process through school education to achieve the desired learning results.
However, the optimists who take this line, who believe the problem lies in identifying and overcoming specific deficiencies at different levels of the school system, face critics who argue that what is needed is a more searching review of the relationship between education and schooling, or between the intellectual and moral formation of the individual and the learning acquired in schools. These more radical analysts warn against the fundamental mistake of arbitrarily identifying the two terms, education and schooling. By trying to resolve all the problems that arise in forming individuals, they say, the optimists have lost sight of the more limited sense of schooling, which is to teach a series of skills, knowledge and attitudes that are the basis of personal development and life in society (Coll, 1999; Letwin, 2000).

These critics have highlighted the way all responsibility related to the development of children and young people has been transferred to the schools, and simultaneously removed from all other institutions (Coll, 1999). Their social environment is seen as harmful to the pupils' physical, psychological and moral health, and at the same time the influence of the family is also 
2 Las propuestas y experiencias surgi-
das en torno a este concepto de das en torno a este concepto de encontrarse en: Learning Communities Network, www.lc-network.com, en el que se presentan antecedentes acerca del programa desarrollado en Gran Bretaña, inclayendo documentos de referencia. En www.bcn.es/imeb/pec,

iniciativas que incluye el proyecto desarrollado por la ciudad de Barcelona:
PEC- Projecte Educatiu de Ciutat. En la dirección www.ala.asn.au/cities.html, se presenta el proyecto de educación de adultos desarrollado en Australia, propuesto como una red de aprendizaje comunitario ajustaso carencias específicas que presentan los distintos niveles del sistema escolar, se alza un conjunto de voces críticas que plantean que es necesaria una revisión más profunda de la relación entre la educación y la escolarización, es decir, entre la formación intelectual y moral de las personas y el aprendizaje en las escuelas. Desde esta perspectiva de crítica más radical se advierte que el error fundamental está en que se ha llegado a una identificación arbitraria de ambos términos, educación y escolarización. Se afirma que en el intento de dar solución a todos los problemas que plantea la formación de las personas se ha perdido de vista el sentido más restringido del aprendizaje escolar, que es el de enseñar un conjunto de conocimientos, destrezas y actitudes que son la base del desarrollo personal y de la vida en sociedad (Coll, 1999; Letwin, 2000) .

En esta perspectiva crítica, se ha puesto de relieve que el traspaso de todas las responsabilidades relacionadas con el desarrollo de los niños y los jóvenes a la educación escolar ha implicado simultáneamente una des-responsabilización del resto de las instituciones sociales en esta tarea (Coll, 1999). El entorno social se percibe como nocivo para la salud física, psicológica y moral de los niños y los jóvenes, en una situación agravada por el debilitamiento de la influencia familiar. Estas condiciones han hecho de los centros educativos un lugar que se considera adecuado para proteger a los niños y los jóvenes del abandono y la negligencia, de las carencias físicas y afectivas, de la violencia, el abuso sexual y las drogas. Se espera también que la educación escolar garantice el desarrollo de hábitos de vida saludables y de formas de convivencia colaborativa que preparen a los alumnos a integrarse a la sociedad. La experiencia ha demostrado, sin embargo, que estas demandas no pueden ser una tarea exclusiva de los profesores y las actividades escolares (Ghilardi, 1993). La importancia del conocimiento y del dominio tecnológico en el contexto globalizado actual plantea exigencias de una formación amplia y continua que superan los recursos con los que cuentan los centros escolares (Barberá, 2003). En este escenario han surgido iniciativas que plantean la necesidad de hacer de la educación una tarea social más amplia, en la que participen activamente las distintas instituciones de la sociedad. El caso del Proyecto Educativo de Ciudad, llevado adelante por la ciudad de Barcelona desde 1988, permite ilustrar esta postura innovadora acerca de la educación (Institut d'Educació de Barcelona, 1998). A través de este

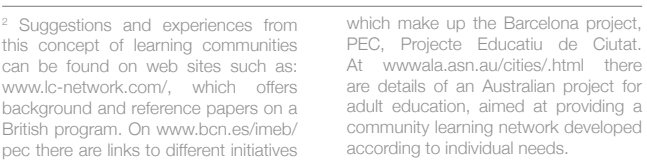

proyecto se ha revisado el papel de los municipios y de la ciudad en la organización y la provisión de servicios educativos, generándose un conjunto de iniciativas en las que todos los sectores aportan a la educación, desde su área de especialidad, en ámbitos tan diversos como la conservación del patrimonio artístico o el reciclaje de los residuos. Cada una de estas instituciones ha sido invitada a reflexionar y a proponer experiencias para aportar a la educación de las nuevas generaciones. En otras ciudades y regiones, especialmente en Gran Bretaña, Australia y Canadá, han surgido también proyectos similares, desde $1990^{2}$. En ellos se ha aplicado el concepto de comunidades de aprendizaje, como una forma de poner de relieve la responsabilidad compartida con la que es necesario llevar adelante la educación de las nuevas generaciones (Yarnit, 2000). En un contexto en el que el conocimiento está ampliamente distribuido y se renueva a un ritmo vertiginoso, parece necesario distribuir también la tarea de traspasarlo, cambiando sustancialmente el perfil del educador y de su actual marco institucional. ARQ

Bibliografía: Barberá, Elena; "Profesores para la era de la Información ¿Cuál es el perfil?”. Pensamiento Educativo, Vol. 32, 2003, pp. 190-203. / Barnard, Anne; "Growing weakening. These conditions have transformed the school into the place where children and young people must be protected from neglect, from the lack of physical and affective care, and from sexual abuse and drugs. Schooling is also expected to ensure that the pupils develop the healthy life styles and collaborative social relations they will need to fit into society. But experience has shown that these tasks cannot be left entirely to the teachers and to school activities (Ghilardi, 1993). The importance of knowledge and technological skills in today's globalized world creates demands for broad, continuous education that is well beyond the resources of the schools (Barberá, 2003).

The new scenario has prompted initiatives that present the need to make education a broader, social task, where different social institutions participate actively. Barcelona's Projecte Educatiu de Ciutat (City Educational Project), in place since 1988, is an example of this innovative stance (Institut d'Educació de Barcelona, 1998). The aim of the project is to look at the role of the municipalities and the city in organizing and providing educational services, and from there to generate initiatives where all sectors can contribute from their own specialization in aspects that range from preserving the artistic heritage to recycling waste. Each institution has been invited to review and propose ways of contributing to the education of future generations. Since 1990, different cities and regions in Britain, Australia and Canada $^{2}$ have all produced similar projects, applying the concept of learning communities as a way of emphasizing the shared responsibility for progress in education (Yarnit, 2000). In a world where knowledge is widely distributed and expanding boundaries at breakneck speed, what is needed is a re-distribution of the work of passing it on. That implies substantial changes in the profile of the teacher and his current institutional framework. ARQ

Bibliography: Barberá, Elena; "Profesores para la era de la Información ¿Cuál es el perfil?”. Pensamiento Educativo, Vol. 32, 2003, pp. 190-203. / Barnard, Anne; "Growing with equity: Social change and challenges to education in Chile". In: Mazurek, K.; Winzer, M. y Majorek, C. (Eds.); Education in a global society: A comparative perspective Allyn \& Bacon, Boston, 2000. Bruer, John T.; Schools for thought: A science of learning in the classroom. MIT Press, Cambridge, Massachusetts, 1993. / Coll, César; "Algunos desafíos de la educación básica en el umbral del nuevo milenio". Perfiles Educativos, 83/84, 1999. pp. 8-26. / Delors, Jacques; La educación encierra un tesoro. Ediciones UNESCO, París, 1996. / Filp, Johanna; Cardemil, Cecilia; Donoso, Sebastián; Torres, Jaime; "La escuela ¿cómplice del fracaso escolar?". Revista de Tecnología Educativa (OEA), No4, Vol. 7, 1981, pp. 340-358. / Ghilardi, Francesco; Crisis y perspectivas de la profesión docente. Gedisa, Barcelona, 1993. / Institut d'Educació de Barcelona Projecte Educatiu de Ciutat; Barcelona educació. Monogràfic $\mathrm{N}^{\circ}$ 2, Barcelona, 1998. / Letwin, Olivier; "Objetivos de la enseñanza escolar: La importancia de la base". Estudios Públicos, 78, 2000, pp. 165-172. Marchesi, Alvaro, Martín, Elena; Calidad de la enseñanza en tiempos de cambio. Alianza Editorial, Madrid, 1998. / National Commission on Excellence in Education; A nation at risk: The imperative for educational reform. $A$ report to the nation and the Secretary of Education, United States Department of Education, Washington, 1983. / Ravitch, Diane; Left back: A century of failed school reforms. Simon \& Schuster, Nueva York, 2000 ( Stanton, Jessie; "The ideal teacher and how she grows". Young Children, May 1990, p.19. / Yarnit, Martin; Towns, cities and regions in the learning age: $A$ survey of learning communities. A report submitted to the CERI/OCDE, 2000 
with equity: Social change and challenges to education in Chile". En: Mazurek, K.; Winzer, M. y Majorek, C. (Eds.); Education in a global society: A comparative perspective. Allyn \& Bacon, Boston, 2000. / Bruer, John T.; Schools for thought: A science of learning in the classroom. MIT Press, Cambridge, Massachusetts, 1993. / Coll, César; "Algunos desafíos de la educación básica en el umbral del nuevo milenio". Perfiles Educativos, 83/84, 1999. pp. 8-26. / Delors, Jacques; La educación encierra un tesoro. Ediciones UNESCO, París, 1996. / Filp, Johanna; Cardemil, Cecilia; Donoso, Sebastián; Torres, Jaime; "La escuela icómplice del fracaso escolar?". Revista de Tecnología Educativa (OEA), No4, Vol. 7, 1981, pp. 340-358. / Ghilardi, Francesco; Crisis y perspectivas de la profesión docente. Gedisa, Barcelona, 1993. / Institut d'Educació de Barcelona Projecte Educatiu de Ciutat; Barcelona educació. Monogràfic No 2, Barcelona, 1998.

/ Letwin, Olivier; "Objetivos de la enseñanza escolar: La importancia de la base". Estudios Públicos, 78, 2000, pp. 165-172. / Marchesi, Alvaro, Martín, Elena; Calidad de la enseñanza en tiempos de cambio. Alianza Editorial, Madrid, 1998. National Commission on Excellence in Education; $A$ nation at risk: The imperative for educational reform. A report to the nation and the Secretary of Education, United States Department of Education, Washington, 1983. / Ravitch, Diane; Left back: A century of failed school reforms. Simon \& Schuster, Nueva York, 2000. / Stanton, Jessie; "The ideal teacher and how she grows". Young Children, Mayo, 1990, p.19. / Yarnit, Martin; Towns, cities and regions in the learning age: $A$ survey of learning communities. A report submitted to the CERI/ OCDE, 2000.

\section{Exteriores de los edificios educacionales Tomás Browne}

Un arquitecto, casi instintivamente para tener palabra -escrita u oral-acerca de la arquitectura, se ubica en un "lugar" y trae a presencia los edificios que sitúan lo que se pretende afirmar. Situarse y sitiar desde un lugar, coloca al arquitecto a una distancia en la cual es posible contemplar el espacio del que se quiere hablar, y hacer de éste un asunto arquitectónico.

En virtud de lo dicho, y para hablar de los edificios destinados a la educación, comienzo haciendo el catálogo de los edificios que he tenido presentes como telón de fondo de esta reflexión. No me referiré a los colegios que fundaron las colonias de extranjeros residentes en el país, porque en sus comienzos ellos se constituyeron autónomamente respecto del desarrollo de la educación en Chile.

Los liceos: Instituto Nacional, Barros Arana, Manuel de Salas, Liceo $\mathrm{N}^{o} 1$ de Niñas de Viña del Mar y el Liceo $\mathrm{N}^{\circ} 7$ de Providencia; los colegios de los SS.CC. de la Alameda y posteriormente de Manquehue, San Ignacio de Alonso Ovalle y Pocuro, y el de los Padres Alemanes en Bellavista, posteriormente Verbo Divino en Presidente Errázuriz; también el colegio Saint George de la Pirámide, casi todos en la ciudad de Santiago.

Este texto no es acerca de la historia de las escuelas como institución, iniciadas como "escuelas palatinas" por Carlomagno en el siglo VIII. Tampoco trata del desarrollo de éstas en nuestro país a partir del siglo XIX (fecha en la que comienzan a construirse edificios cuyo destino exclusivo era el impartir educación) a los tiempos actuales. En todo caso, antes de mediados del siglo XIX en Chile, la educación se impartía en edificios ideados para otros usos. El punto de vista del texto es aquel del habitante de la ciudad, que camina por el exterior de estas escuelas y colegios, para luego adentrarse en ellos. Ocurre por tanto que quien recorre estos edificios primeramente por su exterior y es detenido para entrar en ellos, se detiene ante una concreta fachada.

La fachada es en arquitectura aquello que se presenta con mayor integridad. La fachada permite de-morar el recorrido por la ciudad, a diferencia del interior que es el morar de

\section{School building exteriors \\ Tomás Browne}

When an architect needs words, either written or spoken, for architecture, almost instinctively he "locates" himself by bringing to mind the buildings that place what he wants to say. Situating and surrounding himself in a place gives him the distance from which to contemplate the space he wants to talk about, transforming it into a matter of architecture.

So in order to talk about buildings for education I shall start with a list of the buildings that provided the backdrop for this reflection. I shall not refer to the schools set up by the expatriate communities, because initially they were formed outside the national educational tradition.

The state schools (liceos): Instituto Nacional, Barros Arana, Manuel de Salas, Liceo $\mathrm{N}^{\circ} 1$ for Girls in Viña del Mar, and Liceo $\mathrm{N}^{\circ} 7$ in Providencia. The religious foundations (colegios): the Sacred Hearts in Alameda, later in Manquehue, San Ignacio de Alonso Ovalle and Pocuro, and the Padres Alemanes in Bellavista, later to become the Verbo Divino in Presidente Errázuriz; and Saint George in La Pirámide, almost all of them in Santiago.

This article will not discuss the history of schools as institutions (dating back to the Palatine Schools founded by Charlemagne in the $8^{\text {th }}$ century), nor the development of schools in Chile up to the present day, beginning in the early $19^{\text {th }}$ century, when the first buildings designed exclusively as schools began to go up. Before that date, education took place in buildings meant for other uses. Rather, this is the viewpoint of an inhabitant of the city, as he walks past the outside of these schools and then is drawn inside. In this process, the subject's attention is arrested by the outside, the facade.

The facade, architecturally speaking, is the building's most integral expression. It is the facade that slows us in our tour of the city, whereas the interior holds the city within it. The slowdown, the delay at the facade, the experience of being held by it in its integrity, by the conception of the building, raises at first hand the question of what it means in a historic context, and its relationship with the decision to construct city and country. 